\title{
Ebb and Flow Production of Petunias and Begonias as Affected by Fertilizers with Different Phosphorus Content
}

\author{
Erin James and Marc van Iersel ${ }^{1}$ \\ Department of Horticulture, Georgia Station, The University of Georgia, 1109 \\ Experiment Street, Griffin, GA 30223-1797
}

Additional index words. ebb and flood, subirrigation, $\mathrm{pH}$, electrical conductivity, EC, nutrition, Petunia $\times$ hybrida, Begonia $\times$ semperflorens

\begin{abstract}
Water conservation is increasingly important for growers in the United States, but there is little information on the use of alternative irrigation systems, such as ebb and flow, for the production of bedding plants. The objective of this study was to quantify the growth of Petunia Xhybrida Hort. Vilm.-Andr. 'Blue Frost' and Begonia $\times$ semperflorenscultorum Hort. 'Ambassador Scarlet' grown in an ebb and flow system in three soilless media and fertilized with $P$ at 0,50 , or $100 \mathrm{mg} \cdot \mathrm{L}^{-1}$ in the fertigation solution. After 5 weeks, plants grown with 50 or $100 \mathrm{mg} \cdot \mathrm{L}^{-1} \mathrm{P}$ had greater dry weight, height, and width than plants grown with $0 \mathrm{mg} \cdot \mathrm{L}^{-1} \mathrm{P}$. Begonias grown with 50 or $100 \mathrm{mg} \cdot \mathrm{L}^{-1} \mathrm{P}$ had $38 \%$ more flowers than did those grown without $P$. Petunias flowered 4 to 7 days earlier when no $P$ included in the fertilizer. Growing media had little effect on the plants. Begonias grown in Metro-Mix 220 had more inflorescences than those grown in Metro-Mix 366Coir. Changes in electrical conductivity (EC) and $\mathrm{pH}$ of all three media were similar over the course of the experiment. The EC dropped during the third and fourth week and rose again in the fifth week. The pH of the leachate from all three media dropped by an average of 1 unit during the experiment. The results indicate that petunias and begonias may be grown successfully with ebb and flow irrigation, using a variety of fertilizers and growing media. However, $P$ must be included in the fertigation solution for optimal plant quality.
\end{abstract}

As the population of the United States increases, so does the demand on the limited water supply. We probably will see legal restrictions on both the amount of water used in greenhouse operations and the amount of fertilizer runoff allowed to reenter the water supply in the near future (Poole and Conover, 1992). In Europe, alternative irrigation systems, such as ebb and flow, have long been used to address these problems (Molitor, 1990). The economic implications of using subirrigation systems include less labor input required in comparison with traditional irrigation systems, and more even applications of water, leading to a more uniform crop (Elliott, 1990; Uva et al., 1998). Subirrigation systems also reduce runoff (Klock-Moore and Broschat, 1999), thereby reducing water and fertilizer use and costs. However, the adoption of alternative irrigation systems in most of the United

Received for publication 1 June 1999. Accepted for publication 24 Aug. 2000. This paper is a portion of a thesis submitted by E.J. in partial fulfillment of MS degree requirements at The Univ. of Georgia. Mention of brand names is for informational purposes only and does not imply its approval to the exclusion of other products that may also be suitable. We would like to thank Sunbelt Greenhouses for their donation of plant material and the Scotts Co. for the donation of the growing media. The cost of publishing this paper was defrayed in part by the payment of page charges. Under postal regulations, this paper therefore must be hereby marked advertisement solely to indicate this fact.

${ }^{1}$ To whom requests for reprints should be addressed. E-mail address:mvanier@gaes.griffin.peachnet.edu
States has been slow, in part due to a lack of information available to growers.

Although general fertilization guidelines are available for bedding plants as a group, there are many genera, and general recommendations are not adequate for all species (Joiner et al., 1983). Furthermore, guidelines that are available for traditional watering systems, such as overhead or drip irrigation, may not be appropriate for subirrigation systems, which are inherently different in the how they affect the growing environment of the plants.

Much of the research done on begonia nutrition concerned the use of slow release fertilizers at different rates and with overhead watering systems (Chase and Poole, 1987; Witte and Sheehan, 1974). Using subirrigation, we recently have shown that growth of begonia is maximized when the fertigation solution has an electrical conductivity (EC) of $1.6 \mathrm{dS} \cdot \mathrm{m}^{-1}\left(225 \mathrm{~m} \cdot \mathrm{L}^{-1} \mathrm{~N}\right)$ (James and van Iersel, 2001). None of these studies have evaluated different levels of specific components of the fertilizers.

Several studies have focused on the use of ebb and flow irrigation in the production of petunia. Using slow-release fertilizer, KlockMoore and Broschat (1999) found that shoot dry weights of subirrigated and hand-watered plants were similar. James and van Iersel (2001) compared different fertilizer concentrations in the irrigation solution and found that growth of subirrigated petunias was maximized when the fertilizer EC was $2.2 \mathrm{dS} \cdot \mathrm{m}^{-1}\left(320 \mathrm{mg} \cdot \mathrm{L}^{-1}\right.$ N). Baas et al. (1995) reported that a luxury level of consumption of $P$ occurred in petunias grown in an ebb and flow system. Plant quality was not affected by varying levels of P unless no $\mathrm{P}$ was incorporated in the growing medium and the level of $\mathrm{P}$ applied in the nutrient solution was $<10 \mathrm{mg} \cdot \mathrm{L}^{-1},<10 \%$ of the recommended $\mathrm{P}$ levels for bedding plant fertilization (White, 1976). Baas et al. (1995) also investigated the use of different $\mathrm{P}$ levels on the production of other bedding plants and poinsettias (Euphorbia pulcherrima Willd. ex Klotsch), using subirrigation, as a potential method of growth regulation. Only with impatiens (Impatiens walleriana Hook. f.) was height reduced without affecting plant quality. This experiment was conducted with tank-mix fertilizers, not the commercially available ones used by many small growers.

The objective of this experiment was to determine the effect of commercially available fertilizers with different levels of $\mathrm{P}$ on the growth of petunias and begonias, when applied through the fertigation solution of an ebb and flow system. While water-soluble fertilizers are available with a wide range of $\mathrm{P}$ levels, optimum levels for bedding plants as a group, or for petunias and begonias specifically are not known. Deficient levels of P may lead to compact, darker green plants and poor flowering, while $\mathrm{P}$ toxicity can interfere with plant uptake of iron, zinc, or copper, causing deficiencies of those micronutrients (Mills and Jones, 1996).

\section{Materials and Methods}

Treatments. Plug seedlings (288 cells/flat) of petunia 'Blue Frost' and begonia 'Ambassador Scarlet' (obtained from Sunbelt Greenhouses, Douglas, Ga.) were transplanted on 15 Aug. 1997 into $10-\mathrm{cm}^{2}$ pots $(510 \mathrm{~mL})$ containing one of three soilless media, Metro-Mix 220, Metro-Mix 366Coir, or Metro-Mix 500 (The Scotts Co., Marysville, Ohio), which differ in their ratios of peat moss, coconut coir, perlite, vermiculite, and pine bark. Initial nutrient concentrations, $\mathrm{EC}$, and $\mathrm{pH}$ of the growing media were determined using the saturated medium extraction method (Warncke, 1986), and the physical properties were determined with the North Carolina State Univ. porometer method (Fonteno and Bilderback, 1993). Of the three media, Metro-Mix 220 is highest in vermiculite content and water-holding capacity (Table 1). Metro-Mix 500 is higher in pine bark and lower in water-holding capacity, and Metro-Mix 366Coir contains coconut coir instead of peat moss, and has a water-holding capacity in between that of Metro-Mix 220 and 500. The three media also vary in their initial charge of $\mathrm{N}, \mathrm{P}$, and $\mathrm{K}$ (Table 1).

The plants were placed on $12 \mathrm{ebb}$ and flow benches $(2.4 \times 1.2 \mathrm{~m}, 1 \times \mathrm{w})$ (Midwest GroMaster, St. Charles, Ill.) and fertilized with solutions of $20 \mathrm{~N}-0 \mathrm{P}-16.6 \mathrm{~K}, 20 \mathrm{~N}-4.4 \mathrm{P}-$ $16.6 \mathrm{~K}$, or $20 \mathrm{~N}-8.8 \mathrm{P}-16.6 \mathrm{~K}$ (Peters $20-0$ 20 High-Cal Peat Lite, 20-10-20 Peat-Lite Special, or 20-20-20 General Purpose; The Scotts Co.). These fertilizers were chosen because they provide identical $\mathrm{N}$ and $\mathrm{K}$ concentrations, but a wide range of $\mathrm{P}$ concentrations. All three fertilizers are recommended for use 
Table 1. Chemical and physical properties of MetroMix (MM) 220, MetroMix 366Coir, and MetroMix 500. Chemical properties were determined with the saturated medium extraction method and the physical properties were determined with the NCSU porometer method.

\begin{tabular}{|c|c|c|c|c|c|c|}
\hline & & EC & & $\mathrm{N}$ & $\mathrm{P}$ & K \\
\hline Properties & Medium & $\left(\mathrm{dS} \cdot \mathrm{m}^{-1}\right)$ & $\mathrm{pH}$ & --- & $\left(\mathrm{mg} \cdot \mathrm{L}^{-1}\right)$ & --- \\
\hline \multirow[t]{4}{*}{ Chemical } & MM220 & 2.00 & 6.2 & 64.50 & 4.8 & 88 \\
\hline & MM366Coir & 2.60 & 5.4 & 76.42 & 3.4 & 345 \\
\hline & MM500 & 1.40 & 5.6 & 63.17 & 4.1 & 153 \\
\hline & & \multicolumn{2}{|c|}{$\begin{array}{l}\text { Total porosity } \\
-\ldots-\ldots--\end{array}$} & $\begin{array}{l}\text { Air space } \\
-\quad(\%)\end{array}$ & \multicolumn{2}{|c|}{$\begin{array}{l}\text { Container capacity } \\
--------\end{array}$} \\
\hline \multirow[t]{3}{*}{ Physical } & MM220 & \multicolumn{2}{|c|}{87.1} & 6.62 & \multicolumn{2}{|c|}{80.4} \\
\hline & MM366Coir & \multicolumn{2}{|c|}{82.1} & 5.33 & \multicolumn{2}{|c|}{76.8} \\
\hline & MM500 & \multicolumn{2}{|c|}{80.1} & 6.48 & \multicolumn{2}{|c|}{73.6} \\
\hline
\end{tabular}

in bedding plant production by The Scotts Co. Nitrogen levels of the fertilizer solutions were $225 \mathrm{mg} \cdot \mathrm{L}^{-1}$. This $\mathrm{N}$ level was shown in a previous experiment (James and van Iersel, 2001) to result in good growth of both subirrigated petunias and begonias. Fertigation solution ECs were $1.2,1.6$, and $1.1 \mathrm{dS} \cdot \mathrm{m}^{-1}$ and $\mathrm{P}$ concentrations 0,50 and $100 \mathrm{mg} \cdot \mathrm{L}^{-1}$ for the $20 \mathrm{~N}-0 \mathrm{P}-16.6 \mathrm{~K}, 20 \mathrm{~N}-4.4 \mathrm{P}-16.6 \mathrm{~K}$, and $20 \mathrm{~N}-8.8 \mathrm{P}-16.6 \mathrm{~K}$ solutions, respectively. Nitrogen sources varied depending upon fertilizer. $20 \mathrm{~N}-0 \mathrm{P}-16.6 \mathrm{~K}$ contained $11 \%$ nitrate $\mathrm{N}$ and $9 \%$ urea $\mathrm{N}, 20 \mathrm{~N}-4.4 \mathrm{P}-16.6 \mathrm{~K}$ contained $12 \%$ nitrate and $8 \%$ ammonium, but $20 \mathrm{~N}-8.8 \mathrm{P}-16.6 \mathrm{~K}$ contained higher levels of ammoniacal $\mathrm{N}$ with $10 \%$ urea, $4 \%$ ammonium, and $4 \%$ nitrate. The potential basicity of $20 \mathrm{~N}-0 \mathrm{P}-16.6 \mathrm{~K}$ was equivalent to $10 \mathrm{~g} \cdot \mathrm{kg}^{-1}$ $\mathrm{CaCO}_{3}$; the potential acidities for $20 \mathrm{~N}-4.4 \mathrm{P}-$ $16.6 \mathrm{~K}$ and $20 \mathrm{~N}-8.8 \mathrm{P}-16.6 \mathrm{~K}$ were equivalent to 199 and $279 \mathrm{~g} \cdot \mathrm{kg}^{-1} \mathrm{CaCO}_{3}$, respectively.

Plants were fertigated simultaneously in the morning as needed, about two or three times a week. Fertilizer solutions were held in $200 \mathrm{~L}$ opaque tanks adjacent to each table. The solution was pumped onto the tables to a depth of $\approx 2 \mathrm{~cm}$, and then drained back into the tanks. The fertigation solution was in contact with the bottom of the pots for $\approx 13 \mathrm{~min}$. When the solution in the tanks was replenished, the EC was readjusted to the set EC level. The water used to mix the solution was low in $\mathrm{Ca}^{2+}(10$ $\left.\mathrm{mg} \cdot \mathrm{L}^{-1}\right)$ and $\mathrm{Mg}^{2+}\left(1.7 \mathrm{mg} \cdot \mathrm{L}^{-1}\right)$, had a low EC $\left(0.1 \mathrm{dS} \cdot \mathrm{m}^{-1}\right)$ and total alkalinity $\left(50 \mathrm{mg} \cdot \mathrm{L}^{-1}\right.$ $\mathrm{CaCO}_{3}$ ), and a $\mathrm{pH}$ of 6.4.

Measurements. Shoot height, width, number of flowers (or inflorescences on begonia), and dry weight were measured weekly for 5 weeks. Height was determined as the distance from the surface of the medium to the top of the plant, width was measured at a place representative for the whole plant, and number of flowers included any buds developed to the point of showing flower color. Four begonia and five petunia shoots were harvested each week and dried in a forced-air oven at $70^{\circ} \mathrm{C}$ for a minimum of $72 \mathrm{~h}$ before dry weight was determined. Media leachate EC and $\mathrm{pH}$ readings were taken periodically over the course of the experiment, using the pour-through method (Wright, 1986). About $150 \mathrm{~mL}$ of water was poured onto the top of the growing medium (within 1-3 h of irrigation) and the first $75 \mathrm{~mL}$ of leachate was collected. The EC and $\mathrm{pH}$ by dry ashing and inductively coupled plasma spectrophotometry (Jarrell-Ash ICAP 9000; Thermo Jarrell Ash Corp., Franklin, Mass.).

Experimental design. The experiment was a split-plot with four replications and repeated measures, with fertilizer $\mathrm{P}$ levels as the main plot and growing medium as the split-plot. The experimental unit was a group of 20 begonia or 25 petunia plants. Data were analyzed separately for both species with repeated measure analysis of variance and regression analysis. Plant weight and height data were log-transformed before analysis to stabilize the variances. If there was an interaction involving time, data were analyzed by sampling time.

\section{Results and Discussion}

were measured with a portable meter (M90; Corning, Corning, N.Y.). The pour-through method was used, because most of the root growth in subirrigation systems normally occurs in the lower half of the growing medium (Argo and Biernbaum, 1995; Kent and Reed, 1996), and the conditions in that part of the container are most important for the physiology of the plants (van Iersel, 2000). The pourthrough method (Wright, 1986; Yeager et al., 1983 ) is a simple and easy method for collecting leachate from the bottom part of the growing medium and can be used to quantify changes in the $\mathrm{EC}$ and $\mathrm{pH}$. It is a good technique for monitoring EC and $\mathrm{pH}$ of subirrigated growing media, because the results are based on that part of the medium where most of the root growth occurs.

Nutritional analysis was performed on the entire shoots of plants harvested 5 weeks after transplanting. Total $\mathrm{N}$ was determined using the Dumas method (Mills and Jones, 1996) using a CNS 2000 analyzer (LECO Corp., St. Joseph, Mich.), while $\mathrm{P}$ and $\mathrm{K}$ were determined
Through the first 4 weeks of the growing period, both species showed similar trends in their shoot dry weight. Begonias and petunias grown with either 50 or $100 \mathrm{mg} \cdot \mathrm{L}^{-1} \mathrm{P}$ had a significantly higher dry weight than those grown with $0 \mathrm{mg} \cdot \mathrm{L}^{-1}$ starting at 3 and 4 weeks after transplanting (WAT), respectively (Fig. 1). During the 5th WAT, both species continued to increase in dry weight, but the increase in petunias was not as large as in previous weeks. There was no significant difference in dry weight between plants grown with 50 vs. $100 \mathrm{mg} \cdot \mathrm{L}^{-1} \mathrm{P}$ throughout the experiment, nor was there a significant difference in shoot weight among plants in the three growing media for either species at $5 \mathrm{WAT}$.

Similar trends were seen in shoot height. At 5 WAT, petunias and begonias fertigated with 50 or $100 \mathrm{mg} \cdot \mathrm{L}^{-1} \mathrm{P}$ were significantly taller than plants receiving no $\mathrm{P}$. There was no significant height difference between plants grown with 50 vs. $100 \mathrm{mg} \cdot \mathrm{L}^{-1}$ (Table 2). Baas et al. (1995) also found that petunia height is

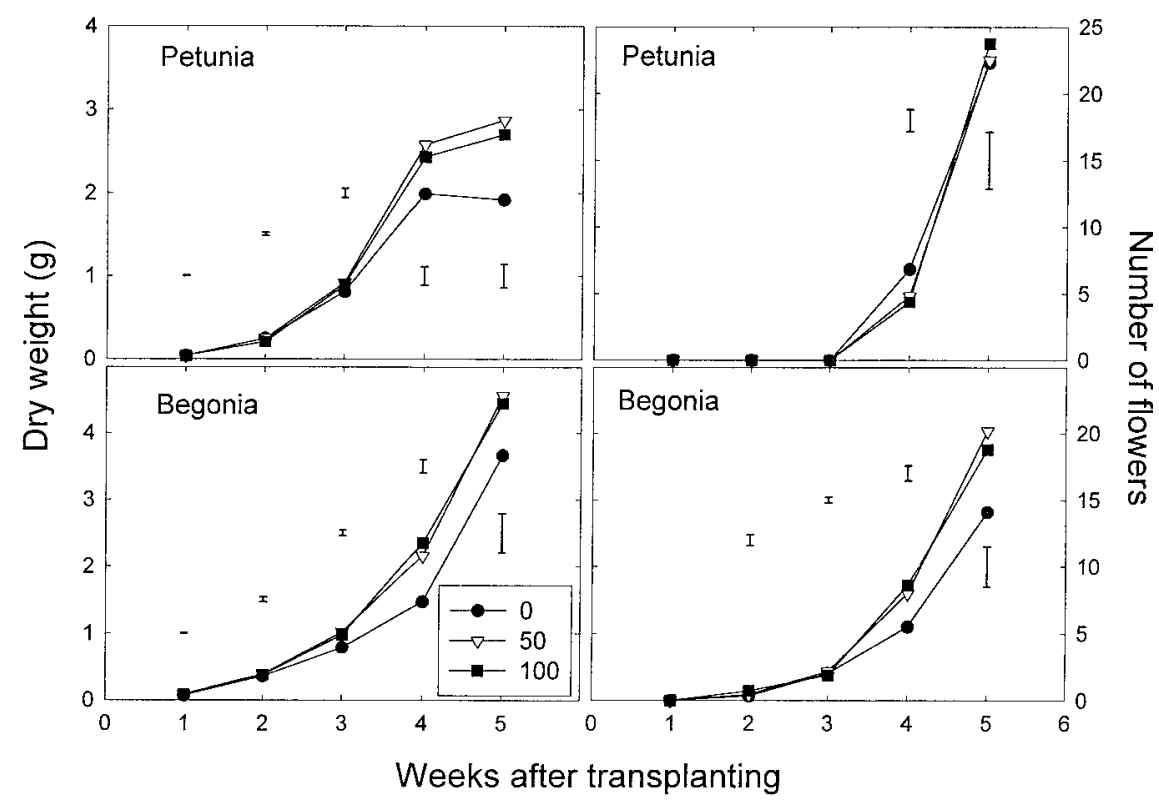

Fig. 1. Main effects of various levels of $\mathrm{P}$ in the fertigation solution on the shoot dry weight and the number of petunia flowers and begonia inflorescences of subirrigated plants. Plants were fertigated with 0,50 , or $100 \mathrm{mg} \cdot \mathrm{L}^{-1} \mathrm{P}$ (from $20 \mathrm{~N}-0 \mathrm{P}-16.6 \mathrm{~K}, 20 \mathrm{~N}-4.4 \mathrm{P}-16.6 \mathrm{~K}$, and $20 \mathrm{~N}-8.8 \mathrm{P}-16.6 \mathrm{~K}$ fertilizers, respectively) with every irrigation event for 5 weeks. Each point represents the mean of 15 (petunia) or 12 (begonia) observations averaged over three growing media. Bars indicate the $\mathrm{LSD}_{0.05}$ values. 
reduced only when very little $\mathrm{P}$ is used $(<2$ $\mathrm{mg} \cdot \mathrm{L}^{-1}$ and no $\mathrm{P}$ incorporated in the growing medium). The width of petunias grown with 50 or $100 \mathrm{mg} \cdot \mathrm{L}^{-1} \mathrm{P}$ was greater than the width of those grown with none. Width of begonias was highest with $50 \mathrm{mg} \cdot \mathrm{L}^{-1} \mathrm{P}$ and lowest with $0 \mathrm{mg} \cdot \mathrm{L}^{-1}$ (Table 2). Plant height, width, dry weight, and flowering of begonias and petunias were adequate with fertilizers containing $\mathrm{P}$ at either $50 \mathrm{mg} \cdot \mathrm{L}^{-1}$ or $100 \mathrm{mg} \cdot \mathrm{L}^{-1}$, but omission of $\mathrm{P}$ reduced plant quality.

Flowering of begonia was not affected by the fertilizers until 4 WAT, when plants not fertilized had the fewest inflorescences. At 5 WAT, begonias fertigated with P (50 or 100 $\mathrm{mg} \cdot \mathrm{L}^{-1}$ ) had $38 \%$ more inflorescences, than did those grown without $P$ (Fig. 1). In contrast, petunias not fertilized with $\mathrm{P}$ flowered 4 to 7 days earlier, and had more flowers at 4 WAT, than did those with $\mathrm{P}$ in the fertilizer solution (Fig. 1). At 5 WAT, there no longer was a significant difference in the number of flowers among petunias fertigated with the three levels of $\mathrm{P}$. The earlier flowering of petunias in the absence of $\mathrm{P}$ in the fertilizer solution is noteworthy information for the bedding plant industry, as it potentially gives growers a tool to shorten the production period. However, Baas et al. (1995) reported fewer flowers on petunia plants fertigated with $2 \mathrm{mg} \cdot \mathrm{L}^{-1} \mathrm{P}$ at 7 WAT, in comparison with those fertigated $\geq 10 \mathrm{mg} \cdot \mathrm{L}^{-1}$ and no effect on time to flowering.

Begonias and petunias showed similar trends in tissue levels of $\mathrm{N}$ and $\mathrm{P}$ (Table 2). Nitrogen levels were $9 \%$ higher in petunias grown with 100 or $50 \mathrm{mg} \cdot \mathrm{L}^{-1} \mathrm{P}$ than in those grown with none. As expected, increasing $\mathrm{P}$ concentrations in the fertilizer solution increased shoot tissue concentrations of P. Tissue $P$ levels in petunias grown with 50 and 100 $\mathrm{mg} \cdot \mathrm{L}^{-1} \mathrm{P}$ were $218 \%$ and $268 \%$ higher than those grown without $\mathrm{P}$, respectively. There were visual differences in plant size among the treatments at 4 and 5 WAT, but no nutrient deficiency symptoms were seen. Combined with the findings of Baas et al. (1995), these results suggest that minimal addition of $\mathrm{P}$ in the fertilizer is needed for petunias and that luxury consumption takes place when extra $P$ is provided. Luxury consumption of $\mathrm{P}$ also occurs in petunia plugs (van Iersel et al., 1998).

There also were significant differences in tissue $\mathrm{N}$ and $\mathrm{P}$ levels among begonias grown with the three different levels of $\mathrm{P}$. Total $\mathrm{N}$ was $24 \%$ and $11 \%$ higher and total P $180 \%$ higher in begonias grown with $100 \mathrm{mg} \cdot \mathrm{L}^{-1}$ and 50 $\mathrm{mg} \cdot \mathrm{L}^{-1} \mathrm{P}$ than in plants grown with none, respectively (Table 2 ). Begonias grown with 0 $\mathrm{mg} \cdot \mathrm{L}^{-1} \mathrm{P}$ were marginally low in tissue levels of $\mathrm{P}$ according to the guidelines of Mills and Jones (1996). There were no visible deficiency symptoms, but, as with the petunias, begonias grown with $0 \mathrm{mg} \cdot \mathrm{L}^{-1} \mathrm{P}$ were visibly smaller than those with $\mathrm{P}$ in the fertigation solution at 4 and 5 WAT.

Differences also were seen in tissue $\mathrm{K}$ levels. Petunias grown with 50 or $100 \mathrm{mg} \cdot \mathrm{L}^{-1}$ $\mathrm{P}$ had similar levels of $\mathrm{K}$, but they were $11 \%$ higher than those grown with no $P$. There were no significant differences in the levels of $\mathrm{K}$ in begonias as a result of $\mathrm{P}$ level (Table 2). Why

Table 2. The effects of different levels of $\mathrm{P}\left(0,50\right.$, and $100 \mathrm{mg} \cdot \mathrm{L}^{-1}$ from $20 \mathrm{~N}-0 \mathrm{P}-16.6 \mathrm{~K}$, $20 \mathrm{~N}-4.4 \mathrm{P}-16.6 \mathrm{~K}$, and $20 \mathrm{~N}-8.8 \mathrm{P}-16.6 \mathrm{~K}$ fertilizers) in the fertigation solution on the height and width and $\mathrm{N}, \mathrm{P}$, and $\mathrm{K}$ levels in the tissue of subirrigated petunias and begonias at 5 weeks after transplanting.

\begin{tabular}{|c|c|c|c|c|c|c|}
\hline \multirow[b]{2}{*}{ Species } & \multirow{2}{*}{$\begin{array}{l}\text { Phosphorus } \\
\left(\mathrm{mg} \cdot \mathrm{L}^{-1}\right)\end{array}$} & \multirow{2}{*}{\multicolumn{2}{|c|}{$\begin{array}{l}\text { Height Width } \\
---(\mathrm{cm})^{---}\end{array}$}} & $\mathrm{N}$ & $\mathrm{P}$ & $\mathrm{K}$ \\
\hline & & & & \multicolumn{3}{|c|}{$----\left(\mathrm{mg} \cdot \mathrm{g}^{-1} \mathrm{DW}\right)^{-}---$} \\
\hline \multirow[t]{3}{*}{ Petunias } & 0 & $15.5 \mathrm{~b}^{\mathrm{z}}$ & $25.4 \mathrm{~b}$ & & & \\
\hline & 50 & $16.5 \mathrm{a}$ & $27.3 \mathrm{a}$ & $58.2 \mathrm{a}$ & $9.5 \mathrm{~b}$ & $67.1 \mathrm{a}$ \\
\hline & 100 & $16.3 \mathrm{a}$ & $27.3 \mathrm{a}$ & $59.6 \mathrm{a}$ & $11.0 \mathrm{a}$ & $66.9 \mathrm{a}$ \\
\hline \multirow[t]{3}{*}{ Begonias } & 0 & $15.7 \mathrm{~b}$ & $21.4 \mathrm{c}$ & $33.1 \mathrm{c}$ & $2.4 \mathrm{~b}$ & $38.1 \mathrm{a}$ \\
\hline & 50 & $18.8 \mathrm{a}$ & $27.0 \mathrm{a}$ & $36.7 \mathrm{~b}$ & $6.5 \mathrm{a}$ & $40.3 \mathrm{a}$ \\
\hline & 100 & $18.1 \mathrm{a}$ & $25.2 \mathrm{~b}$ & $41.0 \mathrm{a}$ & $6.9 \mathrm{a}$ & $38.7 \mathrm{a}$ \\
\hline
\end{tabular}

${ }^{\mathrm{z}}$ Means separation within species and columns by $\mathrm{LSD}_{0.05}$.

the different fertilizers affected the $\mathrm{N}$ and $\mathrm{K}$ concentrations in the shoots is not clear.

Shoot $\mathrm{N}$ and $\mathrm{K}$ concentrations of begonia were within the optimal ranges given by Mills and Jones (1996), suggesting that the differences in shoot $\mathrm{N}$ and $\mathrm{K}$ concentration among the three fertilizer treatments probably were not responsible for the differences in plant growth. Shoot $\mathrm{P}$ concentrations of begonias fertilized with $0 \mathrm{mg} \cdot \mathrm{L}^{-1} \mathrm{P}$ were below the recommended minimum $\left(2.9 \mathrm{mg} \cdot \mathrm{g}^{-1} \mathrm{P}\right.$; Mills and Jones, 1996). There appear to be no reliable sufficiency ranges for petunias in the literature. The fertilizer treatments had large effects on tissue $\mathrm{P}$ concentrations, but relatively small effects on $\mathrm{N}$ and $\mathrm{K}$, while no symptoms of micronutrients deficiencies or toxicities were observed. Thus, most of the fertilizer effects probably were caused by the differences in their $\mathrm{P}$ content, even though the fertilizers also differed in $\mathrm{N}$-form, $\mathrm{EC}, \mathrm{pH}$, and potential acidity.

Leachate EC and $\mathrm{pH}$ of petunias and begonias were affected similarly (Fig. 2). Leachate $\mathrm{pH}$ of plants fertigated with the acidic fertilizers $(20 \mathrm{~N}-4.4 \mathrm{P}-16.6 \mathrm{~K}$ and $20 \mathrm{~N}-8.8 \mathrm{P}-16.6 \mathrm{~K})$

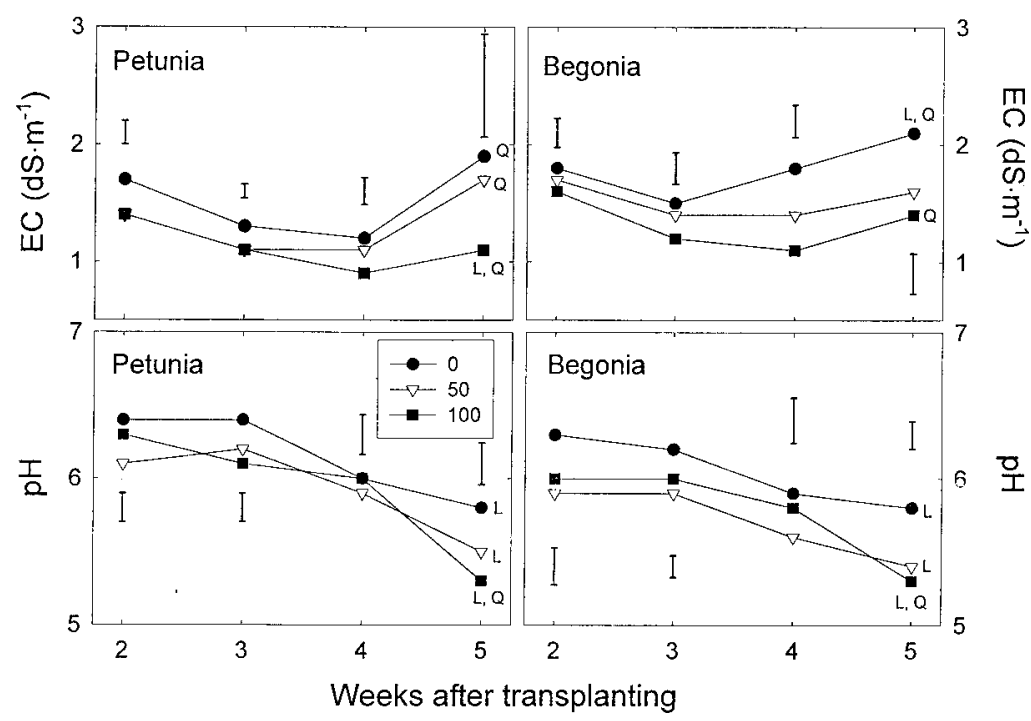

Fig. 2. Main effects of various levels of $\mathrm{P}\left(0,50\right.$, or $100 \mathrm{mg} \cdot \mathrm{L}^{-1}$ from $20 \mathrm{~N}-0 \mathrm{P}-16.6 \mathrm{~K}, 20 \mathrm{~N}-4.4 \mathrm{P}-16.6 \mathrm{~K}$ or $20 \mathrm{~N}-8.8 \mathrm{P}-16.6 \mathrm{~K}$ fertilizers) in the fertigation solution on the $\mathrm{EC}$ and $\mathrm{pH}$ of growing media, as determined with the pour-through method. Petunias and begonias were fertigated with every irrigation event for 5 weeks. L and Q indicate significant linear and quadratic values for $\mathrm{EC}$ or $\mathrm{pH}$ vs. time after transplanting. Data are averaged over three growing media. Bars indicate $\mathrm{LSD}_{0.05}$ values. consistently was lower than that of plants fertigated with the slightly basic $20 \mathrm{~N}-0 \mathrm{P}-$ $16.6 \mathrm{~K}$ fertilizer. The $\mathrm{pH}$ was linearly correlated with time after transplanting in all fertilizer treatments, and dropped by an average of lunit over the course of the experiment. The leachate $\mathrm{EC}$ in the $20 \mathrm{~N}-0 \mathrm{P}-16.6 \mathrm{~K}$ treatment tended to be higher than in the $20 \mathrm{~N}-4.4 \mathrm{P}$ most cases, leachate EC was quadratically associated with time after transplanting. The $\mathrm{EC}$ in all fertilizer treatments was similar at 2 and 5 WAT, but a drop in leachate EC was observed during 3 and 4 WAT followed by a rise 5 WAT (Fig. 2). Leachate of plants grown in Metro-Mix 366Coir had the highest EC, while that of plants grown in Metro-Mix 220 had the highest $\mathrm{pH}$ (results not shown).

The effects of the media on plant growth were much smaller than those of the different fertilizers. No significant differences among media were found in petunia shoot dry weight or number of flowers at 5 WAT, but plants grown in Metro-Mix 366Coir were signifi500. Petunias grown in Metro-Mix 366Coir $16.6 \mathrm{~K}$ and $20 \mathrm{~N}-8.8 \mathrm{P}-16.6 \mathrm{~K}$ treatments. In cantly taller than those grown in Metro-Mix 
and 220 were wider than those grown in MetroMix 500, and begonias grown in Metro-Mix 220 had significantly more inflorescences than those grown in Metro-Mix 366Coir (results not shown).

Growing medium had little effect on tissue nutrient concentration. Petunias grown in Metro-Mix 220 had 7\% more $\mathrm{N}$ than those grown in Metro-Mix 366Coir. Potassium levels in begonias differed significantly in all three media; shoot K concentrations were 19\% and $8 \%$ higher in plants grown in Metro-Mix 366Coir and Metro-Mix 500, respectively, than in plants grown in Metro-Mix 220 (data not shown). These differences in shoot $\mathrm{K}$ concentrations are consistent with differences in the amount of $\mathrm{K}$ in the starter fertilizer of the three media (Table 1).

\section{Conclusions}

Subirrigated petunias and begonias were grown successfully with three different commercially available fertilizers, in three different growing media. However, plants grown with $\mathrm{P}$ in the fertilizer solution had greater shoot dry weight, height, and shoot $\mathrm{P}$ levels than did those grown with no P. Begonias had more inflorescences with $\mathrm{P}$ in the fertilizer solution, while petunias flowered earlier without $\mathrm{P}$. There were no visual nutritional deficiency or toxicity symptoms in plants grown in any of the treatments, although plants of both species grown without added $\mathrm{P}$ were smaller and their quality was reduced. The use of different growing media had little effect on plant growth or tissue nutrient content, indicating that these bedding plants can be grown in a variety of media.

\section{Literature Cited}

Argo, W.A. and J.A. Biernbaum. 1995. The effect of irrigation method, water-soluble fertilization, preplant nutrient charge, and surface evaporation on early vegetative and root growth of poinsettia. J. Amer. Soc. Hort. Sci. 120:163-169.

Baas, R., A. Brandts, and N. Straver. 1995. Growth regulation of bedding plants and poinsettia using low phosphorus fertilization and ebb-andflow irrigation. Acta Hort. 378:129-135.

Chase, A.R. and R.T. Poole. 1987. Effect of fertilizer rate on growth of fibrous-rooted begonia. HortScience 22:162.

Elliott, G. 1990. Reduce water and fertilizer with ebb and flow. Greenhouse Grower 8(6):70-72, 74-75.

Fonteno, W.C. and T.E. Bilderback. 1993. Impact of hydrogel on physical properties of coarse-structured horticultural substrates. J. Amer. Soc. Hort. Sci. 118:217-222

James, E.C. and M.W. van Iersel. 2001. Fertilizer concentration affects growth and flowering of subirrigated petunias and begonias. HortScience 36:40-44.

Joiner, J.N., R.T. Poole and C.A. Conover. 1983. Nutrition and fertilization of ornamental greenhouse crops. Hort. Rev. 5:317-403.

Kent, M.W. and D.W. Reed. 1996. Nitrogen nutrition of New Guinea impatiens 'Barbados' and Spathiphyllum 'Petite' in a subirrigation system. J. Amer. Soc. Hort. Sci. 121:816-819.

Klock-Moore, K.A. and T.K. Broschat. 1999. Differences in bedding plant growth and nitrate loss with a controlled-release fertilizer and two irrigation systems. HortTechnology 9:206-209.

Mills, H.A. and J.B. Jones. 1996. Plant analysis handbook II. MicroMacro Publishing, Athens, $\mathrm{Ga}$.

Molitor, H.-D. 1990. The European perspective with emphasis on subirrigation and recirculation of water and nutrients. Acta Hort. 272:165170

Poole, R.T. and C.A. Conover. 1992. Fertilizers and medium affect foliage plant growth in an ebb and flow irrigation system. J. Environ. Hort. 10:81-86.

Uva, W.L., T.C. Weiler, and R.A. Milligan. 1998. A survey on the planning and adoption of zero runoff subirrigation systems in greenhouse operations. HortScience 33:193-196.

van Iersel, M.W. 2000. Post-production leaching affects the growing medium and respiration of subirrigated poinsettias. HortScience 35:250253

van Iersel, M.W., R.B. Beverly, P.A. Thomas, J.G. Latimer, and H.A. Mills. 1998. Fertilizer effects on the growth of impatiens, petunia, salvia, and vinca plug seedlings. HortScience 33:678-682.

Warncke, D.D. 1986. Analyzing greenhouse growth media by the saturation extraction method. HortScience 21:223-225.

White, J.W. 1976. Fertilization, p. 145-165. In: J.W. Mastalerz (ed.). Bedding plants: A manual on the culture of bedding plants as a greenhouse crop. 2nd ed. The Pennsylvania State Univ., University Park.

Witte, W.T. and T.C. Sheehan. 1974. Effects of media and fertility on growth and flowering of Rieger begonia. Florida State Hort. Soc. 87:508512

Wright, R.D. 1986. The pour-through nutrient extraction procedure. HortScience 21:227-229. 